\title{
Design of Enterprise Application Integration (EAI) in E-Planning and E-Budgeting Systems
}

\author{
Rayandra Yala Pratama ${ }^{1}$ and Febriliyan Samopa ${ }^{2}$
}

\begin{abstract}
Information system integration is needed to support business processes in order to achieve organizational goals. E-Planning and E-Budgeting are systems that are managed by the Department of Communication and Information Technology in Pasuruan Regency. E-Planning is taking part in planning activities, while E-Budgeting is taking part in assigning activities budget. Both systems are working separately that may cause data to exist only in one of those systems. Lacks of data in another system can lead to activity without fund and vice versa. Of course, this problem can disrupt the annual budget plan of the Department of Communication and Information of Pasuruan Regency. This problem can be solved using Enterprise Application Integration (EAI). EAI allows the exchange of data and business processes from several different applications that are interconnected. EAI have 12steps program that come from best practices for system integration. Despite requiring full steps, this research will only take the first seven steps and then proceed with making UML diagrams. The result of this research are UML diagrams such as use case diagram, class diagram, sequence diagram, and object-oriented data model. These designs can represent business processes that are needed for integration process between E-Planning and E-Budgeting system. These designs will be validated through user debriefing and user validation. These designs can be used as references to build a system to integrate E-Planning and E-Budgeting systems.
\end{abstract} EAI.

Keywords-System Integration, E-Planning, E-Budgeting,

\section{INTRODUCTION}

The Department of Communication and Information Technology (CIT) of Pasuruan Regency is a government institution that has the task to manage all government application in Pasuruan Regency. This institution is also responsible for serving other institution request about new application. This department is not only developing the requests by themselves but also throwing them to thirdparty application developers. For those applications which are developed by third-party developer, CIT department only taking part on defining business processes. This behaviour makes CIT department does not get full control on their software development.

\footnotetext{
${ }^{1}$ Rayandra Yala Pratama is with Departement of Business and Management Technology, Institut Teknologi Sepuluh Nopember, Surabaya, Indonesia. E-mail: rayandra.pratama@gmail.com.

${ }^{2}$ Febriliyan Samopa is with Departement of Information System, Institut Teknologi Sepuluh Nopember, Surabaya, Indonesia. E- mail: samopa@gmail.com.
}

With so many applications developed by a third-party developer, make the CIT department difficult to integrate those applications. CIT department needs bigger effort to integrate those applications with different architecture. Simple integration can be achieved through making middleware which is adjusted by integration needs [1].

E-Planning system is a system to manage activities in Pasuruan Regency for next one year or more. While EBudgeting system is to allocate each activity's budget. Both applications run in a chain of a business process. Activities are being planned in e-Planning system and then being allocated with budget in e-Budgeting system. If one of those processes are not fulfilled, then it will cause problems to CIT department and other government institutions in Pasuruan Regency.

This possibility makes integration between e-Planning and e-Budgeting system is a must. Integration makes it possible for them to change data freely. It also can prevent any redundant activities inside e-Budgeting or activity being planned without any budget allocated. Enterprise Application Integration (EAI) represent easiness of changing information and business processes in all information systems that are connected by each other inside an organization [2]. EAI provides solution to solve a problem in an integration process [1].

\section{LITERATUR REVIEW}

\section{A. Previous Study}

EAI can be used to integrate warehouse information system and health center information system [3]. This integration happened in data level EAI. EAI as a middleware also can be used to integrate government applications [4]. Another integration happened using EAI in three different level, process, data and user interface [5].

\section{B. E-Planning and E-Budgeting System}

E-Planning system is an application that is developed to help the Regional Development Planning Agency (Bappeda) in the activities of planning, controlling, and evaluating the implementation of regional development plans.

The e-Budgeting application is web-based software that functions in the preparation of the regional budget. This system was built to help organization unit and the Regional Government Budget Team (TAPD) in preparing budgets and can improve quality, accountability for expenditure allocations, and the accuracy of account values [6]. 


\section{Enterprise Application Integration (EAI)}

EAI is a process which can make all connected applications and data source in an organization change their data and business processes [6]. EAI is a methodology, a technique that can help organizations shape the diversity of systems, several protocols and data sources and various processes into one [1]. EAI is a solution that provides the ability to combine several applications in a company through interfaces that can unite all applications, databases, and processes that run on an internal or external system [7]. EAI is a solution for applications that are built without thinking about the company's vision or strategy and are only built for certain purposes [8].

\section{EAI Integration Dimension}

In EAI implementation, organization must understand the business processes and data in the system that will be integrated. This is because each implementations have different characteristic. There are four integration dimension in EAI, those are:

1) Data Level

Data level EAI is a process, technique and technology in data moving between data storages. This process can be described as a process that take data from a database, process the data, and store them into another database. Even though it seems simple, but it becomes complicated when it is implemented. This is happened because the organization has hundred of databases and thousand of tables.

The advantage of this level is it needs little costs because the application does not change the application and does not require an application development process in general. Also, the price of technology provides a mechanism to move data between databases is not too expensive when compared to other EAI levels which also require similar technology.

\section{2) Application Interface Level}

Application interface level refers to the use of an interface that can be accessed from either a custom or an application package. Developers use this interface to access business processes and simple information. By using this interface, developers can collect several applications in one package where the application can share business logic and information with other applications. The limits faced by developers are that the interface is only available for specific functions and features.

3) Method Level

Method level EAI allow business logic within a company to be able to share between one application and another. For example, methods for updating customer data can be accessed from several applications. Those applications can access other methods without the need to rewrite each method in the application.

There are many mechanisms for dividing methods between applications, such as distributed objects, application servers, transaction processing monitors, frameworks, and creating a new application that combines two or more applications. There are two approaches, namely making a shared server application that is on a physical server (application server), or using technologysharing methods such as distributed objects to share methods

\section{4) User Interface Level}

Although the user interface level is an oldfashioned approach, this approach is quite important. In using this scenario, developers can connect multiple applications using the interface of each application as an integration point. For example, the application provides access through the application interface even though the application does not provide access to the database or business process

\section{E. 12-Step Program Linthicum}

There are many methods in EAI implementation where the method has thousands of steps to achieve the successful implementation of EAI. However, thousands of steps are not needed by most organizations in EAI implementation. The organization is more in need of good architectural capabilities and a knowledge base related to technological solutions. Linthicum uses several steps such as traditional database design, application design and development. Linthicum suggested using a 12-step program technique in implementing EAI because this step has often been used in the application of EAI [9]. The 12-step program is:

1. Understanding the enterprise and problem domain

2. Making sense of the data

3. Making sense of the processes

4. Identifying any application interfaces

5. Identifying the business events

6. Identifying the data transformation scenarios

7. Mapping information movement

8. Applying technology

9. Testing, testing, testing

10. Considering performance

11. Defining the value

12. Creating maintenance procedures.

\section{MethodologY}

This research mainly discusses EAI for application integration between e-Planning and e-Budgeting. The methodology that is used in this research is 12-steps program that is introduced by David S. Linthicum [9]. The program consists of 12 steps in EAI development from understanding the enterprise and problem domain until maintenance process. But this research only does the design so that it only needs 7 out of 12 steps program. There are four integration level of EAI, those are data level, application interface level, method level, and user interface level. Every level has different process and implementation technique so that it must be defined correctly. 
The $1^{\text {st }}$ International Conference on Business and Management of Technology (IConBMT)

August 3rd 2019, Institut Teknologi Sepuluh Nopember, Surabaya, Indonesia

\section{A. Literature Study}

Literature study is done by gathering and learning literatures that are related to this research. Those are national and interational journals, books, and related documents. Moreover, data and facts are gathered by doing interview with CIT Department's staff.

\section{B. Understanding the Enterprise and Problem Domain}

Understanding the enterprise and problem domain is the most complicated process and spend most of the time. Understanding the problem domain needs organization leaders intervention. This is needed to understand the structure and the content of many information systems within the organization. This process consist of gathering existing issues. Then, those issues are analyzed, modeled, and perfected. All of these processes are carried out to produce a collection of solutions that can be used. The quality of information gathering at this stage affects the next steps.

\section{Making Sense of the Data}

Data is very important for EAI implementation process because many EAI projects are occured in data level. Moreover, EAI need understanding about database even the implementation is happened in other integration levels. The implementation of data level EAI is understanding where the data is, collecting data information, and applying business principal to define the reason why the data is flowing.

\section{Making Sense of the Processes}

Based on the problem domain, a decision regarding the approaches to the organization's business model must be made. It is needed to understand and to make a documentation all business processes and how the relations are made. Business processes can be made by using traditional process-modeling technique like UML.

\section{E. Identifying Any Application Interface}

Knowing application interface that support application interface level EAI is a must. Each interface is created different and unique based on the application. Not every interface is the real interface, so that it takes some times to ensure the assumption about interface. First step is to make application interface directory. This directory contain application interface information with its documentation.

\section{F. Identifying the Business Events}

Next process is to identify all business events that are happened within the organization. It can be classified as business event if there is an event happened with its reaction. Real example of this business event is credit service in online shop. There are some things that are considered to record the events. Those are:

- What is the cause.

- What happened during the incident took place.

- What are the consequences of ongoing events.

\section{G. Identifying the Data Transformation Scenarios}

This process is to understand how scheme and data transformation which is moving inside the system. This is important to do because data cannot be used before scheme and content of the data are being reset.

\section{H. Mapping Information Movement}

This process is to map information movement from one to another system. Not only information, data element or information interface also being mapped. Furthermore, the reason why the information is moved from the source to the target also needs to be noticed.

\section{Making an Integration System Design}

Before making the design, determining the level of integration must be done. Determining the integration level is done by observing data and facts from both systems [1]. The result is EAI implementation can be done in user interface level.

\section{J. Design Validation}

The validation is conducted to test whether the model produced in this study can meet the integration need. Validation can be done by doing interview with CIT Department staff that are understand both e-Planning and e-Budgeting system flows. Evaluating the EAI models is done by asking these question:

1. Is the use case diagram suitable for integration needs?

2. Does the class diagram meet the integration needs?

3. Have the sequence diagrams succeeded in representing interactinos that occur between objects?

4. Can activity diagram describe the integrated system workflows?

5. Is the conceptual data model suitable for integration needs?

6. Can the integration model desings be used for integration process?

\section{RESULTS AND DISCUSSION}

As mentioned in the previous section, the results of this research are integration system designs. Those designs will be used for integration process between e-Planning and eBudgeting system. Those designs are:

\section{A. Use Case Diagram}

There are four actors involved in this diagram. Those are planning staff, financial staff on planning, financial staff on treasury, and financial staff on reporting. Planning staff is responsible for importing activity data from e-Planning system, exporting activity budget and report data to ePlanning system. Financial staff on planning is responsible for exporting activity data to e-Budgeting system. Financial staff on treasury is responsible for checking and updating activity budget, importing activity budget from eBudgeting system. Financial staff on reporting is responsible for importing report from e-Budgeting system. 
Figure 1 show the use case diagram for integration system model.

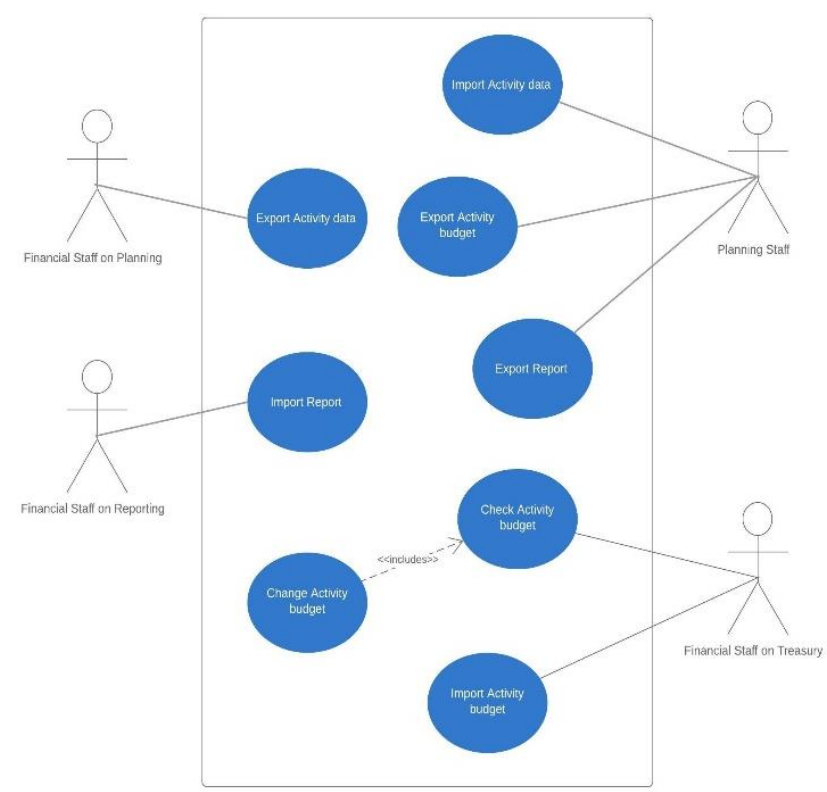

Figure 1. Use case diagram for integration system

\section{B. Class Diagram}

This diagram show classes that are used in integration system. There are two classes in integration system, those are OPD and Activity class. OPD represent regional units while activity represent activity in those units. So, the relationship between those classes is one to many with one OPD has one or more activities. Figure 2 show the class diagram for integration system model.

\section{Sequence Diagram}

There are eight sequence diagrams that describe the flow for each use cases. Figure 3 describe the flow of importing activity data from e-Planning system to integration system.
Figure 4 describe the flow of exporting activity data from integration system to e-Budgeting system. Figure 5 describe the flow of importing activity budget from eBudgeting system to integration system. Figure 6 describe the flow of activity budget checking process. Figure 7 describe the flow of changing activity budget. Figure 8 describe the flow of exporting activity budget from integration system to e-Planning system. Figure 9 describe the flow of importing report data from e-Budgeting system to integration system. Figure 10 describe the flow of exporting report data from integration system to e-Planning system.

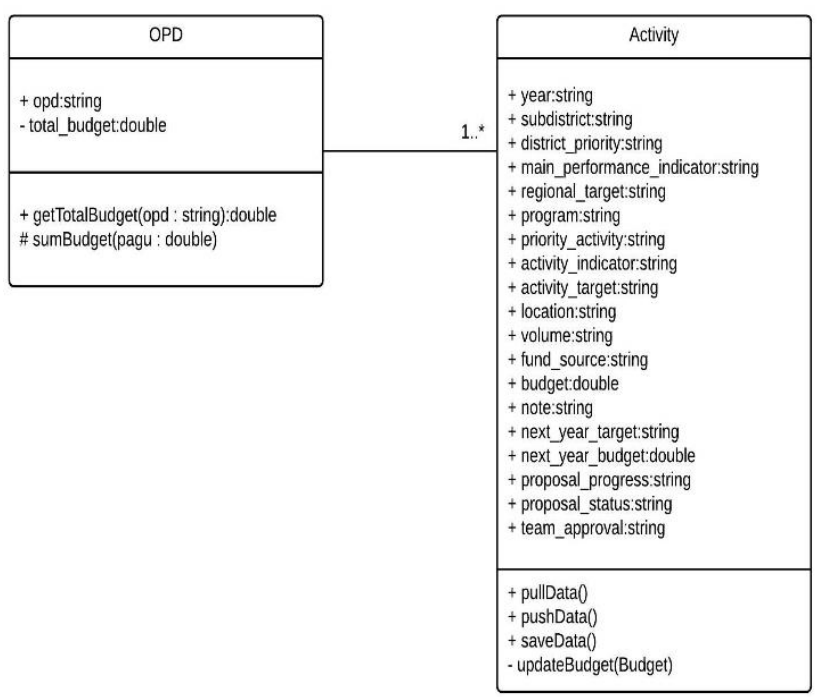

Figure 2. Class diagram for integration system

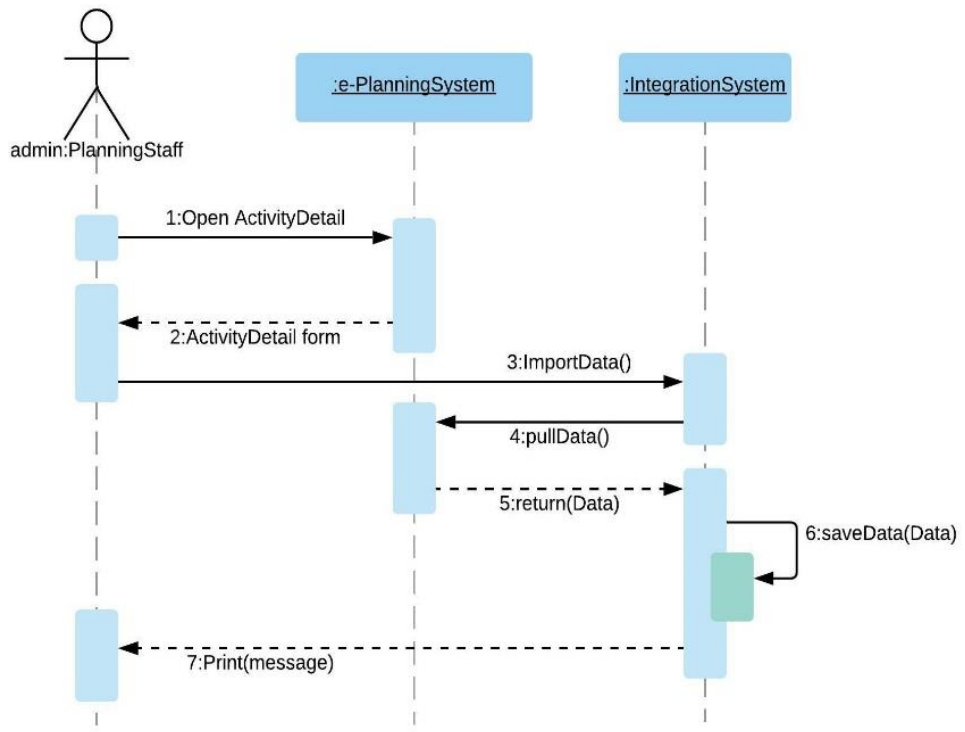

Figure 3. Sequence diagram import activity data 
IPTEK Journal of Proceedings Series No. (5) (2019), ISSN (2354-6026)

The $1^{\text {st }}$ International Conference on Business and Management of Technology (IConBMT)

August 3rd 2019, Institut Teknologi Sepuluh Nopember, Surabaya, Indonesia

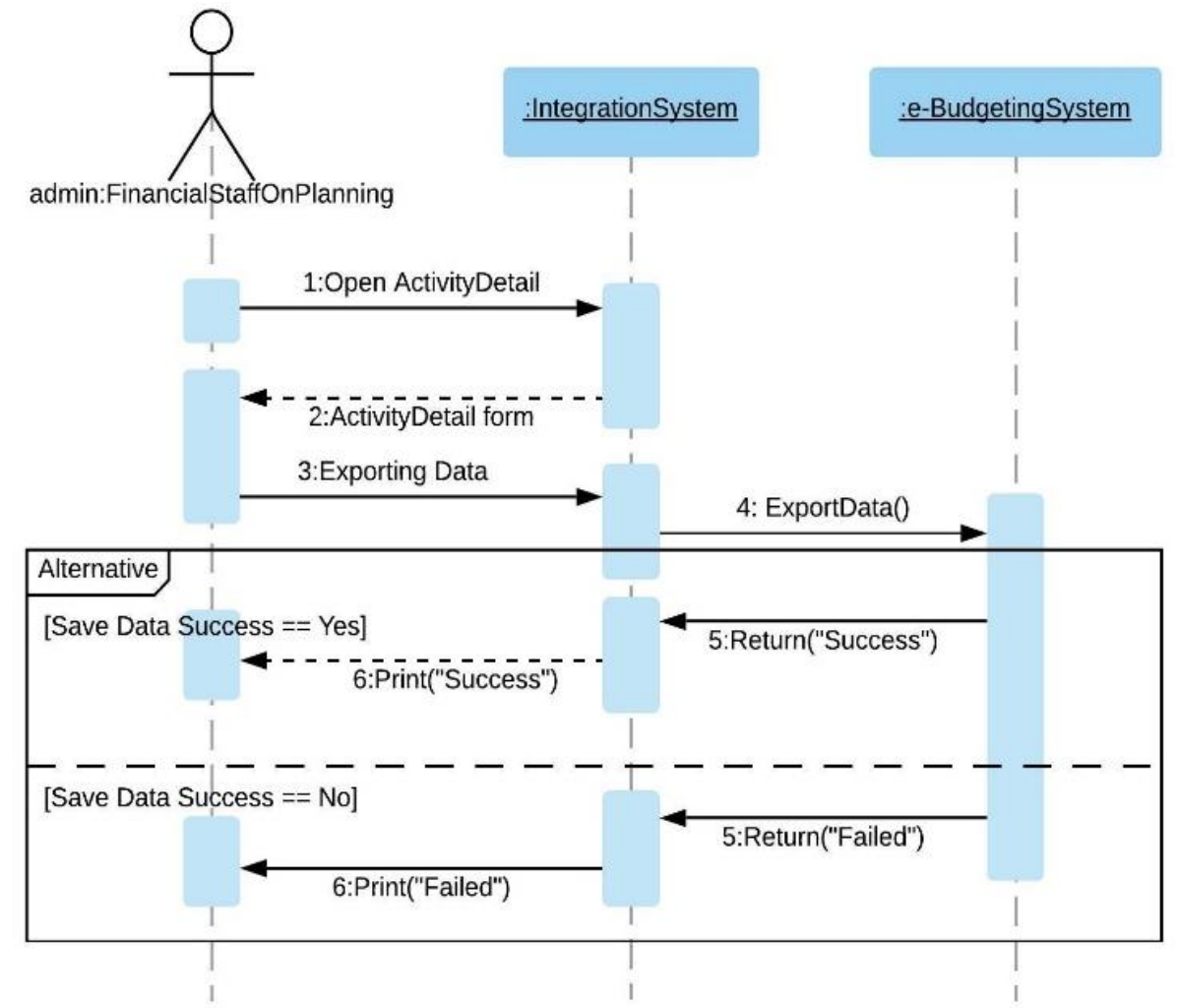

Figure 4. Sequence diagram export activity data

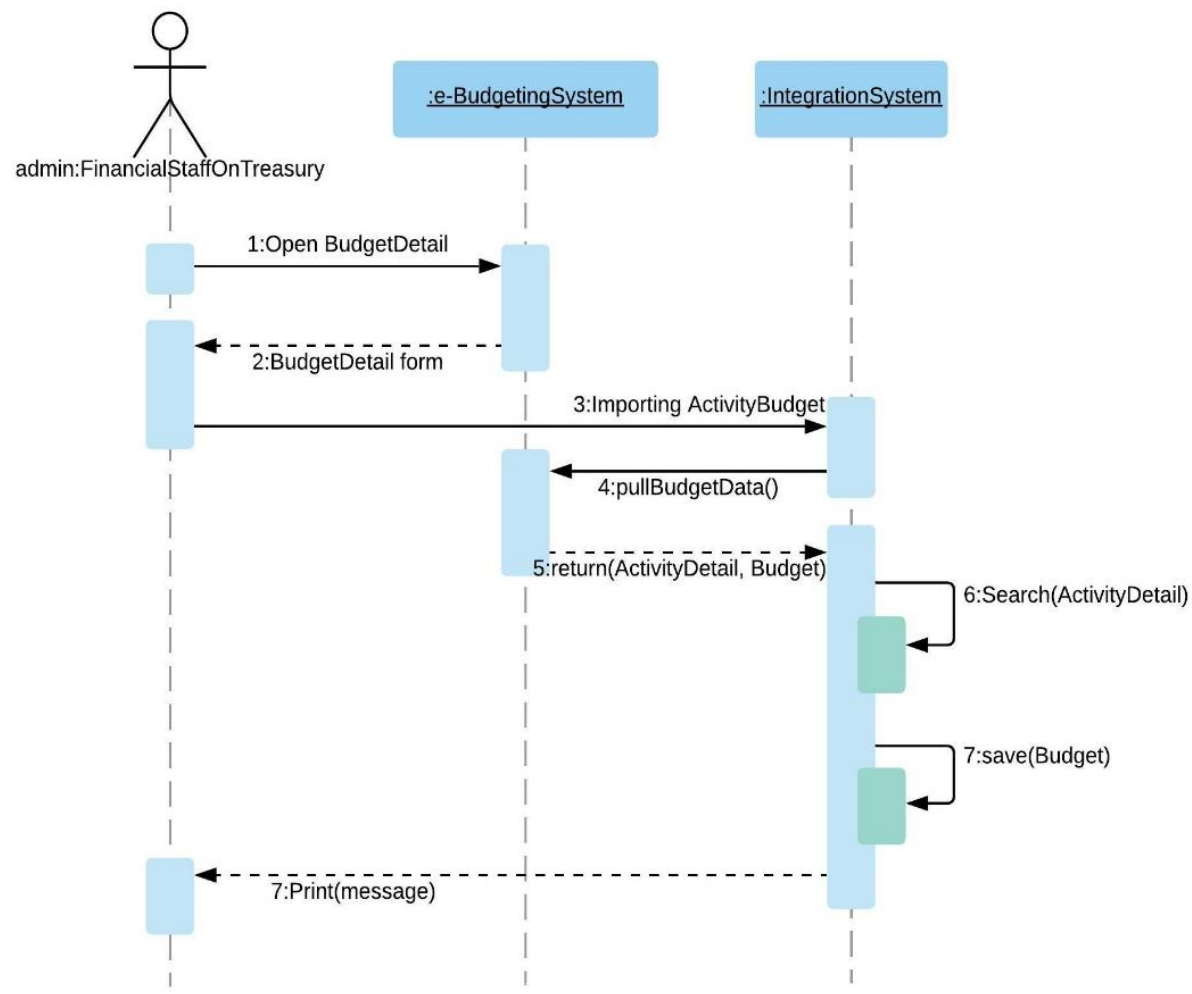

Figure 5. Sequence diagram import activity budget 
The $1^{\text {st }}$ International Conference on Business and Management of Technology (IConBMT) August 3rd 2019, Institut Teknologi Sepuluh Nopember, Surabaya, Indonesia

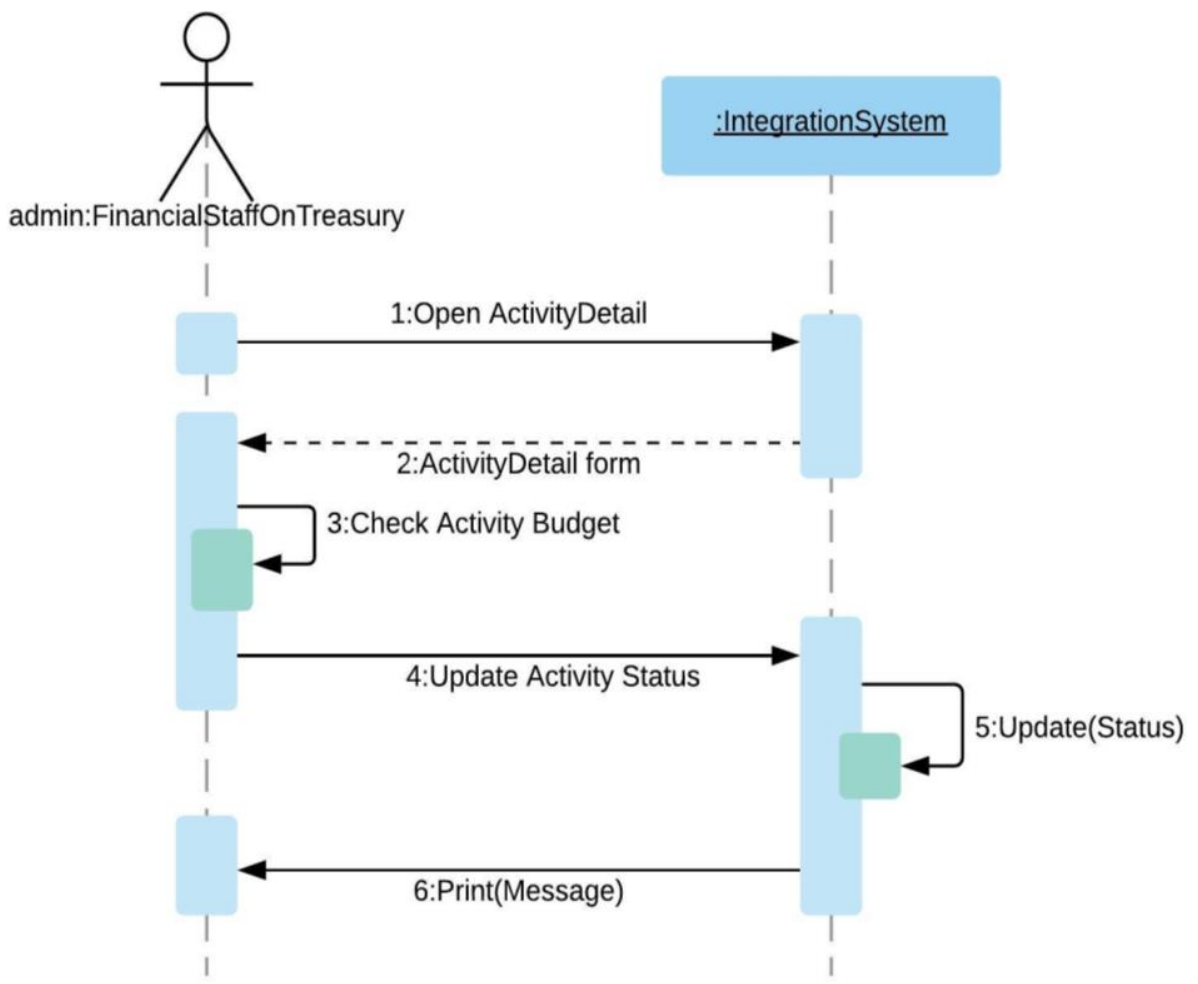

Figure 6. Sequence diagram check activity budget

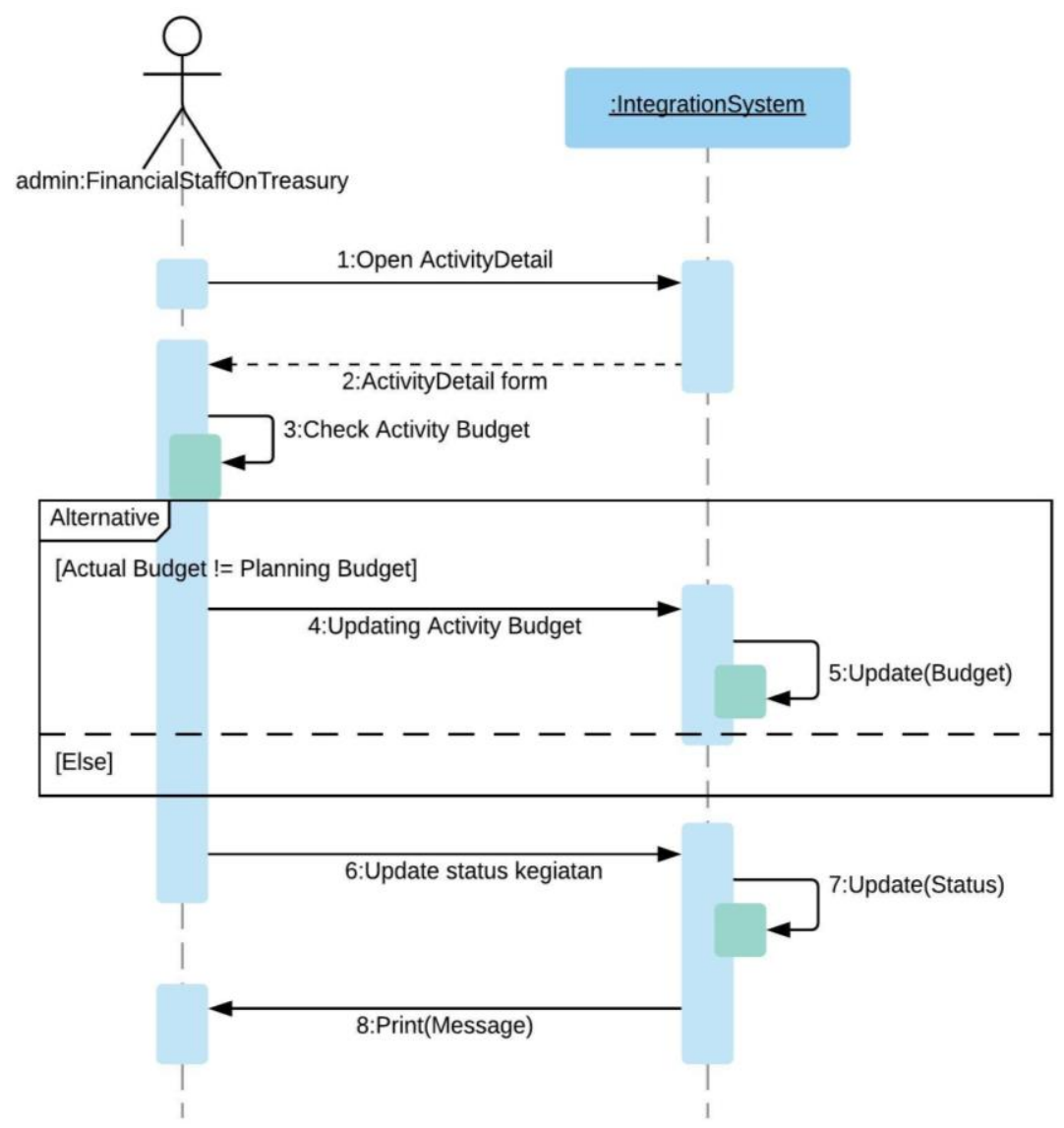

Figure 7. Sequence diagram update activity budget 
IPTEK Journal of Proceedings Series No. (5) (2019), ISSN (2354-6026)

The $1^{\text {st }}$ International Conference on Business and Management of Technology (IConBMT)

August 3rd 2019, Institut Teknologi Sepuluh Nopember, Surabaya, Indonesia

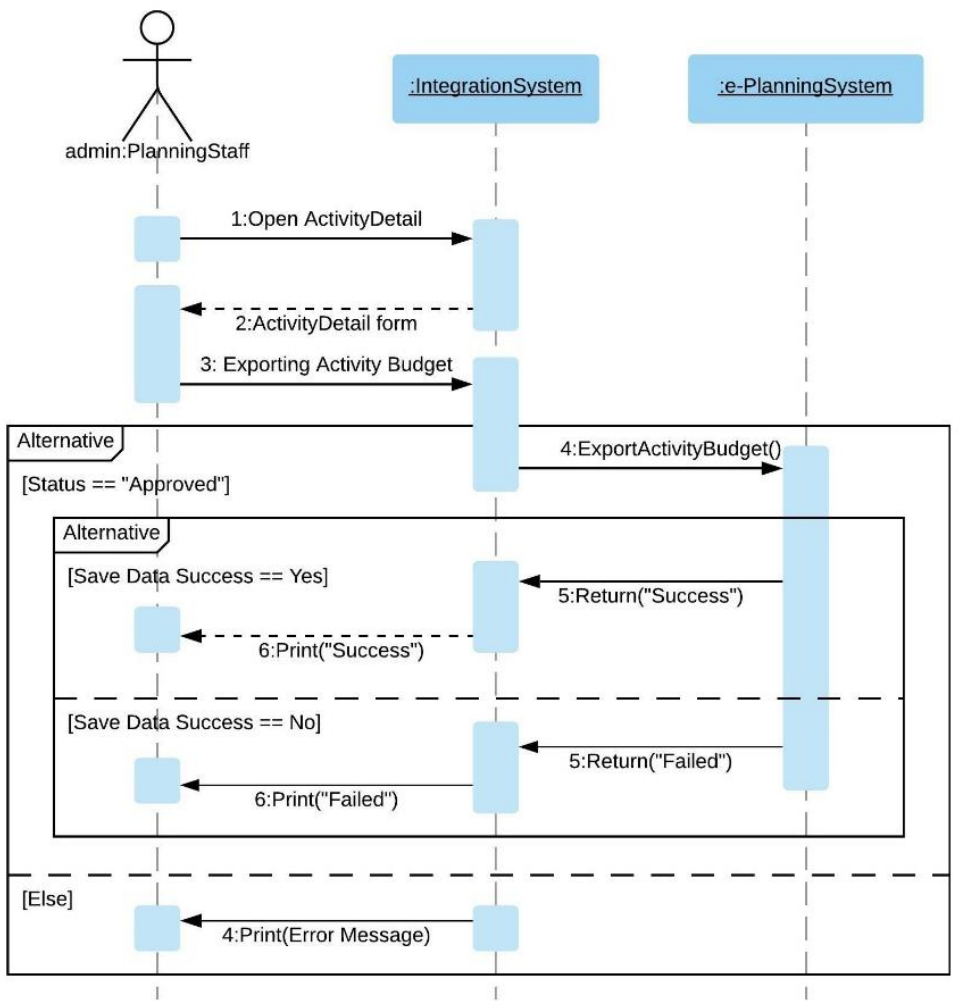

Figure 8 . Sequence diagram export activity budget

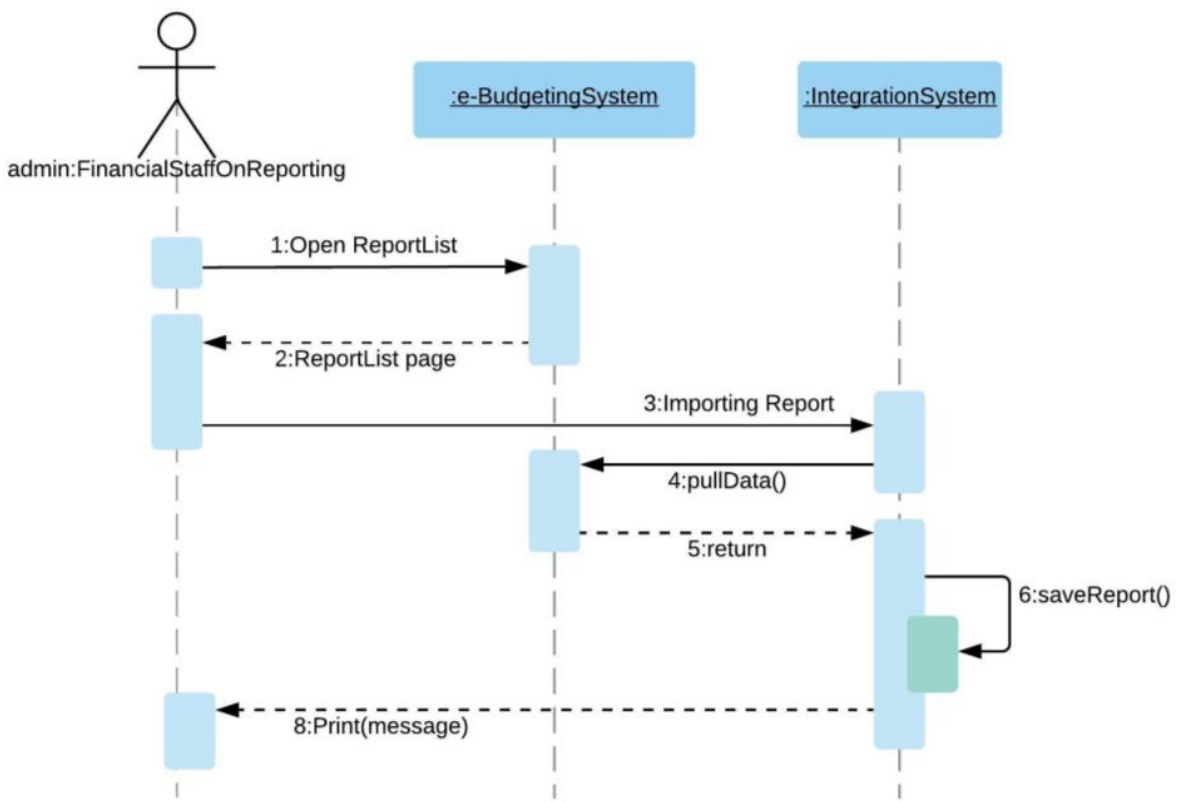

Figure 9. Sequence diagram import report 
The $1^{\text {st }}$ International Conference on Business and Management of Technology (IConBMT) August 3rd 2019, Institut Teknologi Sepuluh Nopember, Surabaya, Indonesia

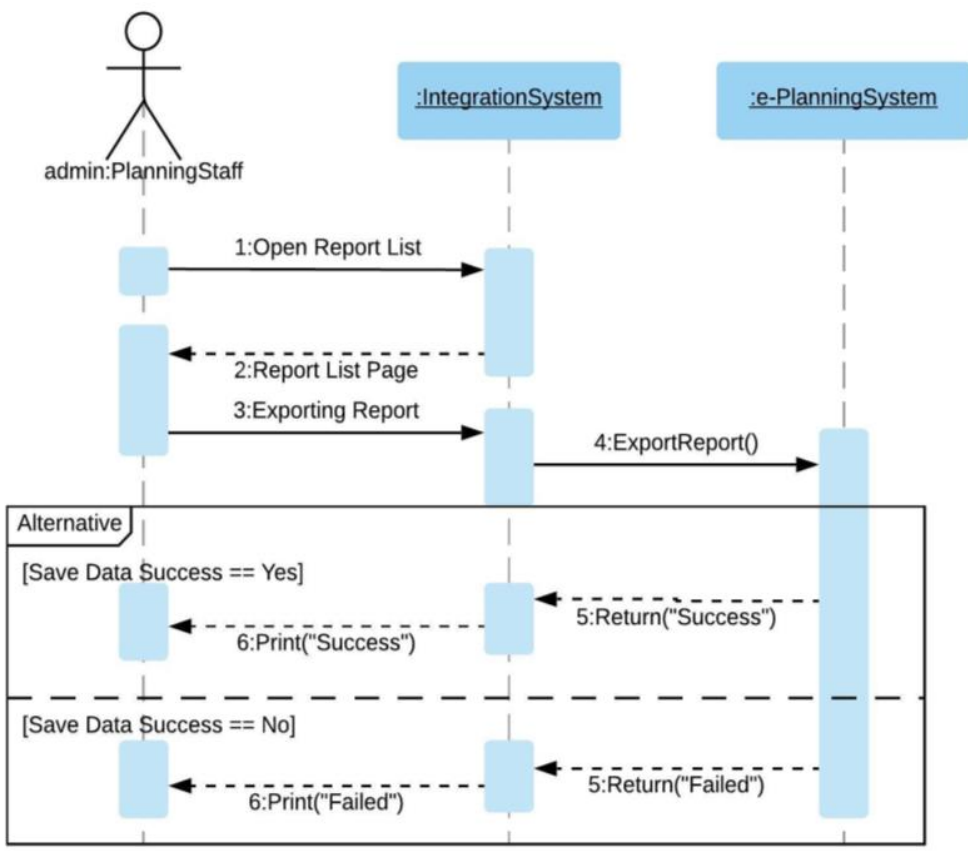

Figure 10. Sequence diagram export repor

\begin{tabular}{|c|c|}
\hline OPD & Activity \\
\hline $\begin{array}{l}\text { + opd:string } \\
\text { - total_budget:double }\end{array}$ & $\begin{array}{l}\text { + year:string } \\
\text { + subdistrict:string } \\
\text { + district_priority:string } \\
\text { + main_performance_indicator:string } \\
\text { + regional_target:string } \\
\text { + program:string } \\
\text { + priority_activity:string } \\
\text { + activity_indicator:string } \\
\text { + activity_target:string } \\
\text { + location:string } \\
\text { + volume:string } \\
\text { + fund_source:string } \\
\text { + budget:double } \\
\text { + note:string } \\
\text { + next_year_target:string } \\
\text { + next_year_budget:double } \\
\text { + proposal_progress:string } \\
\text { + proposal_status:string } \\
\text { + team approval:string }\end{array}$ \\
\hline
\end{tabular}

Figure 11. Conceptual data model for integration system

\section{Activity Diagram}

This diagram shows the activity flow in integration system. The flow starts from importing activity data in ePlanning system until exporting report from integration system to e-Planning system. Full diagram can be seen in Figure 12.

\section{E. Conceptual data model}

This model represents the database which is will be used for the integration system model. Figure 11 show the conceptual data model that is used in integration system model.

\section{F. Design validation}

The result of this research is integration system model which consist of use case diagram, class diagram, sequence diagram, activity diagram, and conceptual data model. Those designs will be validated through interview with CIT Department staff. The results are:

1. Use case diagram is suitable for integration needs.

2. Class diagram can represent classes that are needed for integration needs. 
The $1^{\text {st }}$ International Conference on Business and Management of Technology (IConBMT)

August 3rd 2019, Institut Teknologi Sepuluh Nopember, Surabaya, Indonesia

3. Sequence diagrams have succeeded in representing interactions that occur between objects.

4. Activity diagram can represent the integrated system workflows.

5. Conceptual data model can describe the database for integration system.

Integration model desings can be used for integration process.

\section{CONCLUSIONS}

1. EAI can be used to integrate e-Planning and eBudgeting systems at user interface level with screen scraping techniques.

2. The EAI design can prevent data errors such as planned activities without budget allocation or budget allocated into empty or wrong activity plans. This error can be prevented because the data from the ePlanning and e-Budgeting system has been integrated.

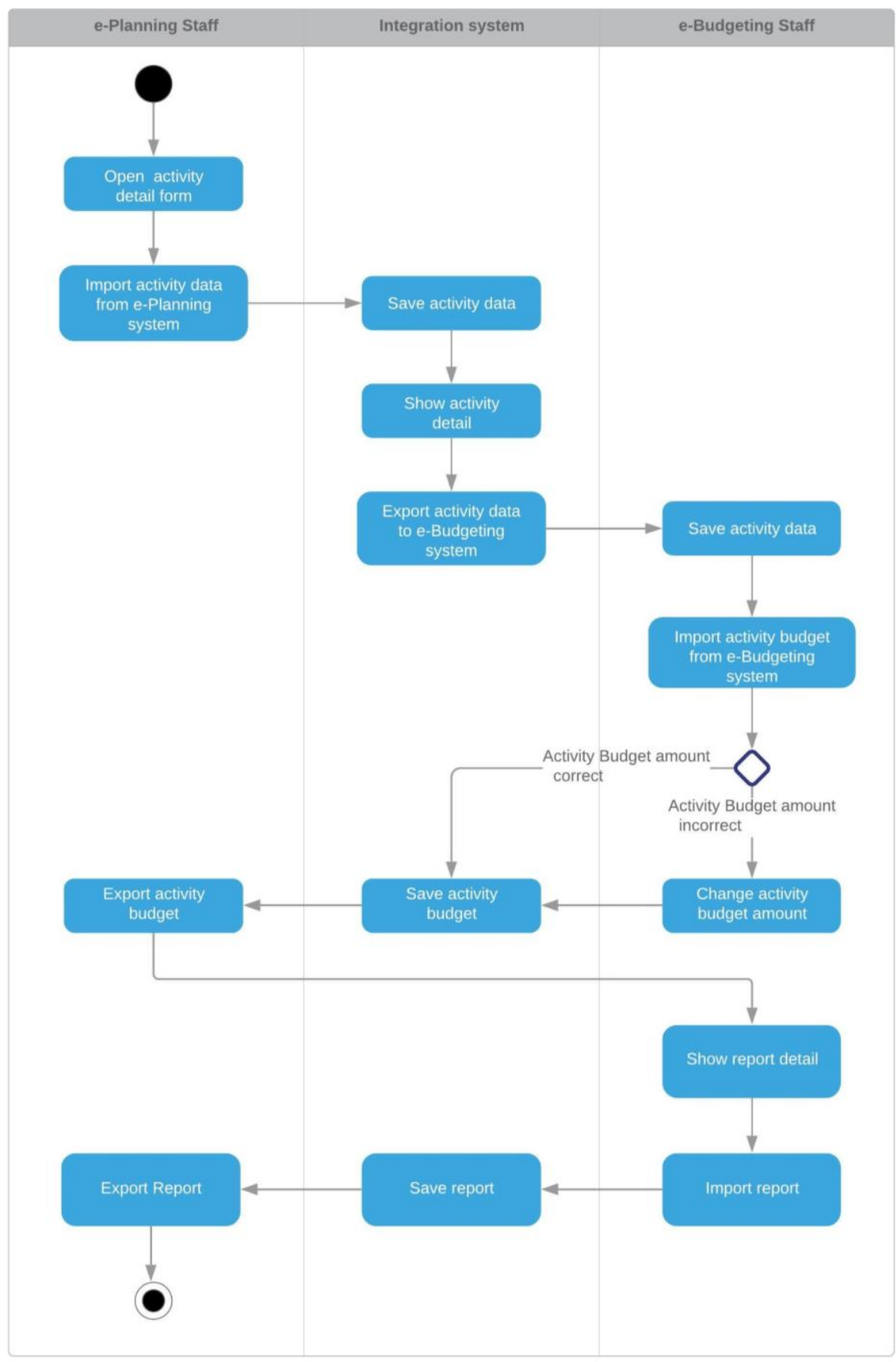

Figure 12. Activity diagram for integration system 
The $1^{\text {st }}$ International Conference on Business and Management of Technology (IConBMT)

August 3rd 2019, Institut Teknologi Sepuluh Nopember, Surabaya, Indonesia

\section{REFERENCES}

[1] B. Özkarabacak, E. Çevik, and P. Y. Gökşen, "A comparison analysis between ERP and EAI," in Procedia Economics and Finance, 2014, vol. 9, pp. 488-500.

[2] N. Erasala, D. C. Yen, and T. M. Rajkumar, "Enterprise application integration in the electronic commerce world," Comput. Stand. Interfaces, vol. 25, no. 2, pp. 69-82, 2003.

[3] R. K. Rahardiansyah, "Implementasi Enterprise Application Integration (EAI) Pada Sistem Informasi Milik Gudang Farmasi Kesehatan dan Puskesmas di Dinas Kesehatan Pemerintah Kabupaten Sidoarjo," Institut Teknologi Sepuluh Nopember, 2014.

[4] T. H. Prasetyo and F. Hijrih, "Desain arsitektur Enterprise Application Integration (EAI) sebagai middleware untuk aplikasi pemerintah (e-government)," in Proceedings Konferensi Nasional Sistem dan Informatika (KNS\&I), 2015, pp. 148-152.
[5] G. Karya, "Penerapan enterprise application integration sebagai model integrasi sistem informasi di Universitas Katolik Parahyangan," in Seminar Nasional Teknologi Informasi \& Komunikasi Terapan 2012 (Semantik 2012), 2012, pp. 182-188.

[6] R. Khoirunnisak, D. Arishanti, and D. D. Vebriant, "Penerapan e-budgeting Pemerintah Kota Surabaya dalam mencapai good governance," in Prosiding Seminar Nasional dan Call For Paper Ekonomi dan Bisnis (SNAPER-EBIS 2017), 2017, pp. 249-256.

[7] A. A. M. Al-Ghamdi and F. Saleem, "Enterprise application integration as a middleware: Modification in data \& process layer," in Proceedings of 2014 Science and Information Conference, SAI 2014, 2014, pp. 698-701.

[8] T. R. Soomro and A. H. Awan, "Challenges and future of enterprise application integration," Int. J. Comput. Appl., vol. 42, no. 7, pp. 42-45, 2012

[9] D. S. Linthicum, Enterprise Application Integration. Harlow, England: Addison-Wesley, 1999. 